\title{
AN IMPROVEMENT IN THE TECHNIQUE OF VOGT'S METHOD OF SKELETON-FREE RADIOGRAPHY OF THE BULB. CREATION OF AN EXOPHTHALMOS
}

BY

Dr. Marguerite Kaelin-Sulzer

ASSISTANT AT THE UNIVERSITY EYE CLINIC, $z$ ÜRICH

THE skeleton-free Roentgenograph of the eyeball, which was introduced by Vogt in 1921, has probably become the common property of all oculists.

This method of radiography of the eyeball enables exceedingly small metal particles to be visualized and localized. Previous to 1921 this was not possible, and many an eye was lost after penetration by a small foreign body which could not be found and led to a subsequent siderosis, chalkosis or sympathetic ophthalmitis. With the aid of the Vogt technique it is now possible to save these eyes.

Just such small foreign bodies, having little momentum, are frequently hidden in the anterior part of the globe, especially in the ciliary body, and require a radiograph to reveal their presence and position. When the media are opaque, it is, of course, not possible to locate deeply-seated foreign bodies without the X-ray. A number of authors-Hämmerli, Wieser, Stocker, Knüsel and Pfuhl-mostly connected with the University Eye Clinic, Zürich, have written articles dealing with the above mentioned method, of Vogt.

One disadvantage of the Vogt method is the fact that only the most anterior portion of the eye is accessible. In cases where the globe recedes into the orbit a still smaller region becomes accessible than is the rase in more protruding eyes.

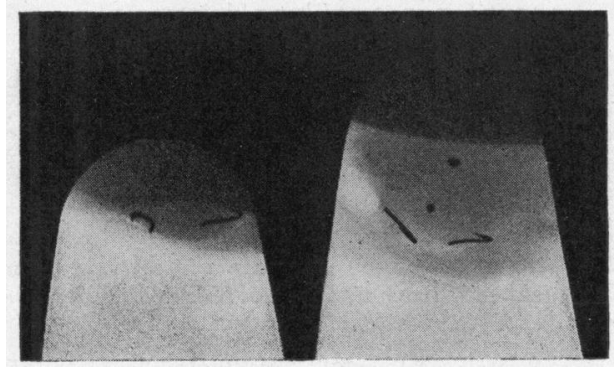

F1G. 1.

FIG. 2 . 
In a case of a boy, aged 12 years, with a somewhat deep-seated eyeball, having intra-ocular copper fragments, we obtained a considerably better view, by creating a slight exophthalmos by means of a retrobulbar injection of a weak ( 1 per cent.) novocain solution. The copper particles which were previously seen near the outer edge of the photograph now came well within the borders of the film, as shown in Fig. 2. Only one fragment was visible on the first radiograph (Fig. 1). Fig. 1 also shows the angle-hooks which were used for localization purposes. Vogt instructed me to inject 3 c.c. of a 1 per cent. novocain solution temporal and posterior to the globe, by means of which the bulb was pushed a few millimetres forward. To our surprise, a second particle, similar in size to the first, was then plainly visible in the photograph.

Of no mean importance was the fact that movements of the globe were reduced during the process of X-raying; on the one hand, because of absence of pain from pressure produced by the film-clasp, on the other hand, through the limited muscle action resulting from the injection. It is therefore strongly recommended, in the future, previous to making a Vogt radiograph, to produce an exophthalmos by means of a retrobulbar injection of a weak novocain solution, so that in this way any particles situated in a more posterior position may be rendered visible.

Moreover, those Roentgenographs taken in the vertical plane, which are, of course, limited by the roof of the orbit, are greatly improved by means of this artificial exophthalmos.

We have found Agfa films very suitable for these skeleton-free radiographs. A double film is used at each exposure, so that the discovery of any defect existing in one of the films is very much simplified. The instrument which is used to hold the film may be obtained from J. Strnad, Mechanic, Cullmannstr. 26, Zürich 6.

\section{BIBLIOGRAPHY}

1. A. Vogt.-Scelettfreie Aufnahmen des vordern Bulbusabschnittes. Schweiz. Med. Wochenschr., Nr. VII, S. 145, 1921.

2. O. Knüse1.-Beitrag zur Diagnosestellung kleinster intra-ocularer Fremdkörper. Schweiz. Med. Wochenschr., Nr. XXXIX, S. 909, 1923.

3. Pfuhl.-Scelettfreie Röntgenaufnahme des vordern Bulbusabschnittes zur Bestimmung sehr kleiner intra-ocularer Fremdkörper. Klin. Monatsbl. f. Augenheilk., Vol. LXX, S. 398, 1923.

4. V. Haemmerli.-Weitere Erfahrungen mit der scelettfreien Röntgenaufnahme des vordern Bulbusabschnittes. Klin. Monatsbl. f. Augenheilk., Vol. LXXIV, S. 681, 1926.

5. S. Wieser.-Weitere Mitteilungen über die scelettfreie Röntgenaufnahme des vordern Bulbusabschnittes nach Prof. Vogt. Klin. Monatsbl. f. Augenheilk., Vol. LXXXI, 1928.

6. F. Stocker.-Ueber den Wert der scelettfreien Röntgenaufnahmen zum Nachweis und zur Localisation von intra-ocularen Fremdkörpern. Klin. Monatsbl. f. Augenheilk., Vol. LXXXIX, 1932. 